\title{
A Comparison of Assay Performance Between the Calcium Mobilization and the Dynamic Mass Redistribution Technologies for the Human Urotensin Receptor
}

Mi Young Lee, ${ }^{1}$ Jihye Mun, ${ }^{1}$ Jeong Hyun Lee, ${ }^{1}$ Sunghou Lee, ${ }^{2}$ Byung Ho Lee, ${ }^{1}$ and Kwang-Seok Oh ${ }^{1,3}$

${ }^{1}$ Research Center for Drug Discovery Technology, Korea Research Institute of Chemical Technology, Daejeon, Republic of Korea. ${ }^{2}$ Department of Biomedical Technology, College of Engineering, Sangmyung University, Cheonan, Republic of Korea. ${ }^{3}$ Department of Medicinal and Pharmaceutical Chemistry, University of Science and Technology, Daejeon, Republic of Korea.

\section{ABSTRACT}

The popular screening method for urotensin (UT) receptor antagonists is to measure the intracellular calcium concentration with a calcium-sensitive fluorescent dye. This assay format has an inherent limitation on the problem related to the fluorescence interference as it involves fluorescent dyes. In the present study, a label-free assay for the screening of UT receptor antagonists was developed by using dynamic mass redistribution (DMR) assay based on label-free optical biosensor. The addition of urotensin II (UII) stimulated a DMR profile to HEK293 cells stably expressing the human UT receptor (HEK293 UT cells) but not on parental cells. The EC 50 value of UII in label-free assay was $4.58 \mathrm{nM}$, which is very similar to that in conventional calcium mobilization assay $(4.15 \mathrm{nM})$. Compared with the calcium mobilization assay for UII ( $Z^{\prime}$ factor, 0.77), the current label-free assay presented improved $Z^{\prime}$ factor $(0.81)$, with a relatively similar $S / B$ ratio (28.0 and 25.6, respectively). The known high-affinity UT receptor antagonists, SB657510, GSK562590, and urantide, exhibited comparable $I C_{50}$ values but rather less potent in the DMR assay than in calcium mobilization. Our DMR assay was able to present various functional responses, including inverse agonism in SB657510 and GSK1562590 as well as partial agonism in urantide. Moreover, the DMR assay exerted the stable antagonist window upon the minimal agonist stimulus. These results suggest that the label-free cell-based UT receptor assay can be applicable to evaluate the various functional activities of UT receptor-related drug candidates.
\end{abstract}

\section{INTRODUCTION}

rotensin II (UII) is a neuropeptide and endogenous ligand of the G-protein-coupled receptor known as a GPR14 or urotensin (UT) receptor. ${ }^{1}$ UII has been generally agreed to be the most potent endogenous vasoconstrictor discovered to date. ${ }^{2}$ UII and its receptor, UT receptor, is widely expressed in cardiovascular system. ${ }^{3}$ The elevated plasma levels of UII and increased levels of its expression have been demonstrated in numerous disease conditions, including hypertension, atherosclerosis, heart failure, pulmonary hypertension, diabetes, renal failure, and metabolic syndrome. ${ }^{4,5}$ Despite this significant therapeutic potential, only few potent UT receptor antagonists have been reported until recently.

As a screening platform for the development of UT receptor antagonists, the calcium mobilization assay has been widely accepted. ${ }^{6,7}$ By adding functional parameters to the conventional receptor binding assay, the calcium data appear more physiologically relevant and calcium readouts for the urotensin receptor have been used successfully for a wide variety of purposes. In principle, the calcium mobilization assay works well for both the agonist and antagonist screening. However, it has the risk of introducing artifacts due to the possible interference by fluorescent and colored compounds. In addition, monitoring of changes in the intracellular calcium level has limitations on functional characterizations, such as partial and inverse agonisms. ${ }^{8}$ Most recently, there is a growing interest in cellbased functional assays with label-free biosensors. ${ }^{9}$ Upon the various label-free technologies, the dynamic mass redistribution (DMR) system has superiority to monitor molecular movements inside cells on receptor activation or deactivation. ${ }^{10-12}$ This superiority is based on the optical biosensor, which can record shifts in wavelength of reflected light in a real time. ${ }^{13}$ These real-time kinetic responses arising from a receptor-ligand or compound interactions present positive and/or negative signals relative to the baseline that can be applied to investigate various functional mechanisms. There is a general concern on the DMR assay because of its lack of specificity for cell surface receptor activation. In fact, DMR signal could be affected by a wide variety of signals from cell surface receptors, such as GPCR, tyrosine kinase, or ion channel. However, despite its drawback, the label-free assay has been regarded as one of the useful techniques to evaluate complicated targets and to expand knowledge areas in addition to those from conventional assay systems.

In this article, the development and validation results of the DMR assay for the UT receptor were described, and its performance was compared with the conventional fluorescence calcium mobilization assay. 


\section{MATERIALS AND METHODS}

\section{Reagents}

Human recombinant UII was purchased from Sigma-Aldrich (St. Louis, M0). As UT receptor selective reference compounds, SB657510 [2-bromo-N-[4-chloro-3-((R)-1-methyl-pyrrolidin-3yloxy)-phenyl]-4,5-dimethoxybenzenesulfonamide $\mathrm{HCl}]^{14}$ was obtained from Sigma-Aldrich, and Urantide [L-Aspartyl-L-penicillaminyl-Lphenylalanyl-D-tryptophyl-L-ornithyl-L-tyrosyl-L-cysteinyl-L-valine cyclic disulfide $]^{15}$ was purchased from Peptide international, Inc. (Louisville, NY). GSK1562590 [4'-[(1R)-1-[[(6,7-Dichloro-3-oxo-2,3dihydro-4H-1,4-benzoxazin-4-yl)acetyl](methyl)amino]-2-(pyrrolidin1-yl)ethyl]biphenyl-3-carboxamide ${ }^{16}$ was synthesized in-house. Dimethyl sulfoxide (DMSO), G418 disulfate salt, and all other reagents were obtained from Sigma-Aldrich. All tissue culture media and reagents were purchased from Lonza (Allendale, NJ). Fibronectin-coated biosensor microplates were obtained from PerkinElmer (Santa Clara, CA).

\section{Cell Culture}

HEK293 cells were grown in Dulbecco's modified Eagle's medium supplemented with 10\% fetal bovine serum. Cells were cultured at $37^{\circ} \mathrm{C}$ under a humidified atmosphere containing $5 \% \mathrm{CO}_{2}$. To establish a stable cell line with UT receptor, the cDNA of UT receptor (UTR2/ GPR14, GenBank accession number NM_018949 except C51T) in pcDNA3. ${ }^{+}$was transfected to HEK293 cell with Lipofectamine 2000 according to the previous report ${ }^{17}$ and manufacturer's instructions. Transfected colonies with maximum calcium responses by UII were selected as stable cells for the UT receptor. During the clonal selection process, the concentration of G418 was kept at $200 \mathrm{~g} / \mathrm{mL}$. To obtain reproducible DMR or calcium responses, cells were split every 3 days before they became confluent at a culture condition of DMEM with 10\% fetal bovine serum (Gibco BRL, Rockville, MD) and discarded after 2-3 months of continuous growth.

\section{DMR Assays}

The DMR assays were performed using the multimode plate reader label-free system (Enspire; PerkinElmer), which is a benchtop plate reader containing Epic label-free technology (Corning Life Sciences, Lowell, MA). One day before performing the DMR assay, HEK293 cells were seeded onto fibronectin-coated biosensor microplate (Enspire-LFC; PerkinElmer) at a density of $1 \times 10^{6}$ cells $/ \mathrm{mL}$ with $30 \mu \mathrm{L}$ of growth medium (30,000 cells/well). Before measuring the DMR signal, cells were washed thrice with assay buffer (Hank's balanced salt solution with $20 \mathrm{mM}$ HEPES and 1\% DMSO) and then transferred within the EnSpire reader for $2 \mathrm{~h}$ at $25^{\circ} \mathrm{C}$. Afterward, a $5 \mathrm{~min}$ baseline was established to ensure the cells reached a steady state. As the first protocol for agonist test, urotensin II or compounds in $10 \mu \mathrm{L}$ of $1 \%$ DMSO with assay buffer were added directly to cells and the DMR was monitored for $30 \mathrm{~min}$. In the second protocol for antagonist test, compounds were added and incubated with cells for $30 \mathrm{~min}$. At the end of incubation, $30 \mathrm{nM}$ urotensin II was added at an 80\% effective concentration approximately, and DMR responses were continuously monitored for another 30 min to determine the inhibition of agonist-

\begin{tabular}{|c|c|c|c|}
\hline Step & Parameter & Value & Description \\
\hline 1 & Cells & $30 \mu \mathrm{L}$ & 30,000 cells/well, overnight \\
\hline 2 & Wash & $25 \mu \mathrm{L} \times 3$ & Pipetting and aspiration \\
\hline 3 & Buffer \#2 & $30 \mu \mathrm{L}$ & $1 \%$ DMSO with assay buffer \\
\hline 4 & Incubation time & $2 \mathrm{~h}$ & Equilibrate in EnSpire $\left(25^{\circ} \mathrm{C}\right)$ \\
\hline 5 & Baseline reading & $4 \min$ & Keep temperature constant \\
\hline 6 & Compound & $10 \mu \mathrm{L}$ & $\begin{array}{l}\text { Compounds in 1\% DMSO } \\
\text { with assay buffer }\end{array}$ \\
\hline 7 & Final reading \# 1 & $30 \mathrm{~min}$ & EnSpire $\left(25^{\circ} \mathrm{C}\right)$ \\
\hline 8 & UII & $10 \mu \mathrm{L}$ & Urotensin II in assay buffer \\
\hline 9 & Final reading \#2 & $30 \mathrm{~min}$ & EnSpire $\left(25^{\circ} \mathrm{C}\right)$ \\
\hline 10 & Analysis & & \\
\hline $\begin{array}{l}\text { Step } ~ \\
\text { 1. Per } \\
\text { see } \\
\text { ove } \\
\text { 2. Da } \\
25 \\
\text { 3. Ad } \\
\text { 4. Equ } \\
\text { equ } \\
\text { 5. Ba } \\
\text { 6. Ad } \\
\text { var } \\
\text { 7. Qu } \\
\text { 8. Ad } \\
\text { 9. Qu }\end{array}$ & $\begin{array}{l}\text { S } \\
\text { ned in EnSpire-LFC } \\
\text { (UT receptor trans } \\
\text { ht. } \\
\text { washing with bu } \\
3 \text { remove all with } \\
\mu \mathrm{L} \text { of buffer \#2. } \\
\text { ate for } 2 \mathrm{~h} \text { in EnSpi } \\
\text { ating, prepare com } \\
\text { e measurement. } \\
\mu \mathrm{L} \text { of compounds } \\
\text { concentrations of } \\
\text { reload plate into } \\
\mu \mathrm{L} \text { of urotensin II } \\
\text { reload plate into }\end{array}$ & $\begin{array}{l}\text { \#2 }(1 \times \text {-well fib } \\
\text { iration. } \\
\text { keep tempe } \\
\text { nd dilution } \\
\text { 4). Columr } \\
\text { npounds. } \\
\text { ire for fin } \\
\text { ire for fin }\end{array}$ & $\begin{array}{l}\text { ectin-coated plates. Day 1: cell } \\
0,000 \text { cells/well), } 37^{\circ} \mathrm{C} \text { incubator } \\
\text { S, } 20 \mathrm{mM} \mathrm{HEPES,} 1 \% \text { DMSO), } \\
\text { ure constant). While cell plate is } \\
\text { ates. } \\
1-3 \text {, buffer \#2; columns } 4-12 \text {, } \\
\text { ead \#1( } 30 \mathrm{~min}) \text {. } \\
\text { ead \#2( } 30 \mathrm{~min}) .\end{array}$ \\
\hline
\end{tabular}

induced DMR response (Table 1). DMR responses were monitored every 1 min over test periods. For profiling, two independent measurements in triplicate were performed.

\section{Calcium Mobilization Assay}

Calcium mobilization was measured on the automated fluorometer, FlexStation II as previously described. ${ }^{18}$ Before the day of experiment, HEK293 $3_{\text {UT }}$ cells at optimum growth were transferred onto black-sided clear-bottom 96-well plates at a density of $1 \times 10^{6}$ cells/ $\mathrm{mL}$ with $100 \mu \mathrm{L}$ of growth medium (100,000 cells/well). After overnight incubation, the homogeneous fluorescence calcium assay dye (FLIPR Calcium 3; Molecular Device, Sunnyvale, CA) in the Hank's balanced salt solution (HBSS) with $20 \mathrm{mM}$ of HEPES and $2.5 \mathrm{mM}$ of probenecid at $\mathrm{pH} 7.4$ was loaded according to the manufacturer's instructions. The plates were then incubated at $37^{\circ} \mathrm{C}$ for $60 \mathrm{~min}$ before being placed in the FlexStation II (MDS Analytical Technologies, 
Sunnyvale, CA). Fluorescence signals were measured every $1.52 \mathrm{~s}$ for the total of $60 \mathrm{~s}$ time frame, and $50 \mu \mathrm{L}$ of $30 \mathrm{nM}$ urotensin II or dye buffer (HBSS with $20 \mathrm{mM}$ of HEPES, pH 7.4) was added to each well in column-wise after $16 \mathrm{~s}$ of the equilibration period. Ten microliters of vehicle (0.5\% DMSO) or compounds were treated $10 \mathrm{~min}$ before the initiation of fluorescence measurements (Table 2). The filter settings were $485 \mathrm{~nm}$ for excitation and $525 \mathrm{~nm}$ for emission, with cutoff wavelength at $515 \mathrm{~nm}$.

\section{Statistical Analysis}

The DMR or calcium mobilization response was calculated by subtracting the baseline measurement from the peak response intensity for each compound concentration. The $\mathrm{EC}_{50}$ and $\mathrm{IC}_{50}$ values from dose-response experiments were analyzed using the nonlinear curve fitting functions in PRISM version 4.0 (GraphPad Software,

\begin{tabular}{|c|c|c|c|}
\hline Step & Parameter & Value & Description \\
\hline 1 & Cells & $100 \mu \mathrm{L}$ & 100,000 cells/well, overnight \\
\hline 2 & Removing the media & & \\
\hline 3 & Loading buffer & $190 \mu \mathrm{L}$ & $2.5 \mathrm{mM}$ probenecid in loading buffer \\
\hline 4 & Incubation time & $30 \mathrm{~min}$ & $37^{\circ} \mathrm{C}$ incubator \\
\hline 5 & Compound & $10 \mu \mathrm{L}$ & $5 \%$ DMSO in HBSS/20 mM HEPES \\
\hline 6 & Incubation time & $30 \mathrm{~min}$ & $37^{\circ} \mathrm{C}$ incubator \\
\hline 7 & Baseline reading & $16 s$ & $\begin{array}{l}\text { Keep constant temperature } \\
\text { in FlexStation }\left(37^{\circ} \mathrm{C}\right)\end{array}$ \\
\hline 8 & UII & $50 \mu \mathrm{L}$ & Urotensin II in assay buffer \\
\hline 9 & Reading & $1 \mathrm{~min}$ & FlexStation II \\
\hline 10 & Analysis & & \\
\hline
\end{tabular}

\section{Step Notes}

1. Performed in 96-well clear-bottom plates (Greiner, \#655090, coated with poly-I-lysine and laminin). Day 1: cell seeding in DMEM with 10\% FBS (UT receptor transfected-HEK293, 100,000 cells/well), $37^{\circ} \mathrm{C}$ incubator overnight.

2. Day 2: remove the supernatant.

3. Add $190 \mu \mathrm{L}$ of loading buffer (diluted the Component A with $2.5 \mathrm{mM}$ probenecid in $1 \times \mathrm{HBSS} / 20 \mathrm{mM}$ HEPES) to each well.

4. Incubate cell plate for $30 \mathrm{~min}$ at $37^{\circ} \mathrm{C}$.

5. Add $10 \mu \mathrm{L}$ of compounds to each wells. Columns $1-2,5 \%$ DMSO only; columns $3-12$, various concentrations of compounds.

6. Incubate cell plate for $30 \mathrm{~min}$ at $37^{\circ} \mathrm{C}$. Transfer the assay plate to the FlexStation II (using SoftMax Pro) assay plate carriage and run.

7. Baseline measurement. The counter settings were excitation at $485 \mathrm{~nm}$ and emission at $525 \mathrm{~nm}$.

8. After $16 \mathrm{~s}$, quickly add $50 \mu \mathrm{L}$ of urotensin II $(\times 5)$ by using dispenser in FlexStation II.

9. Read UII-induced calcium signal for $1 \mathrm{~min}$.

10. Analysis respective $\mathrm{EC}_{50}$ or $\mathrm{IC}_{50}$ values.
Inc., San Diego, CA). The classical equation for sigmoidal dose-response for the nonlinear regression analysis was used. For representations of the quality of assay itself $\left(\mathrm{Z}^{\prime}\right), \mathrm{Z}^{\prime}$ factor was calculated as $1-$ $\left(\left[3 \times \mathrm{SD}_{\mathrm{c}+}\right]+\left[3 \times \mathrm{SD}_{\mathrm{c}-}\right]\right) /\left(\right.$ Mean $\left._{\mathrm{c}+}-\mathrm{Mean}_{\mathrm{c}-}\right)$ and the percent inhibition was calculated as ([raw data of compound-Mean $\left.\mathrm{c}_{\mathrm{c}-}\right] /\left[\mathrm{Mean}_{\mathrm{c}+}-\right.$ Mean $\left.\left._{\mathrm{c}-}\right]\right) \times 100 . \mathrm{SD}_{\mathrm{c}+}$ and $\mathrm{SD}_{\mathrm{c}-}$ are denoted for the standard deviations of the positive control signal and negative control signal, respectively. Mean $\mathrm{c}_{+}$and Mean $\mathrm{C}_{-}$are represented for the means of the positive control signal and negative control signal, respectively.

\section{RESULTS}

\section{DMR Characterization of UT Receptor}

To characterize DMR responses of UT receptor, the optimum cell density for the DMR assay was evaluated as the first step. The addition of $100 \mathrm{nM}$ UII elicited a positive DMR response and the maximum DMR response was observed at a density of 30,000 cells/ well in 384-well plates (Fig. 1A). In DMR agonism assay, the stimulation of UII at various concentrations $(0-100 \mathrm{nM})$ to HEK293 ${ }_{\text {UT }}$ cells evoked a positive DMR response in a concentrationdependent manner (Fig. 1B), and the wavelength shift of $640 \pm 26$ P.M. was observed at the end of measurement with $100 \mathrm{nM}$ UII. The gradual and continuous signal increase was observed approximately $8 \mathrm{~min}$ after UII stimulation, and the rate became steady after $30 \mathrm{~min}$. The calculated $\mathrm{EC}_{50}$ value for UII was $4.58 \pm 1.42 \mathrm{nM}$ (Fig. 1C). With parental HEK293 cells, no DMR response was generated (Fig. 1D).

\section{Calcium Mobilization Characterization of UT Receptor}

Calcium levels were monitored using the automated fluorometer, FlexStation II, and the homogeneous calcium dye, Calcium 3. The maximum calcium signal was observed at a density of 100,000 cells/well in 96-well plates (Fig. 2A), and UII evoked calcium signal in a concentration-dependent manner (Fig. 2B). The calculated $\mathrm{EC}_{50}$ value for UII was $4.15 \pm 1.06 \mathrm{nM}$ (Fig. 2C). The calcium response in parental HEK293 cells was not observed (Fig. 2D).

\section{Comparison of $\mathrm{IC}_{50}$ Values of Known UT Receptor Antagonists}

SB657510, GSK1562590, and urantide as the known UT receptor antagonists were used to analyze their concentration-dependent antagonist responses. All the compounds showed a typical concentrationdependent antagonist response. As shown in Figure 3, $\mathrm{IC}_{50}$ values of SB657510, GSK1562590, and urantide in the DMR assay were $1,880 \pm 138,47.4 \pm 13.7$, and $10.7 \pm 1.1 \mathrm{nM}$, respectively, which were less potent than those from the calcium mobilization assay (528 \pm 163 , $3.3 \pm 0.7$, and $8.1 \pm 0.36 \mathrm{nM}$, respectively).

\section{Evaluation of Assay Quality and Validity}

The quality of DMR and calcium mobilization assays for the screening of UT receptor antagonists was evaluated by the Z' factor 


\section{LEE ET AL.}
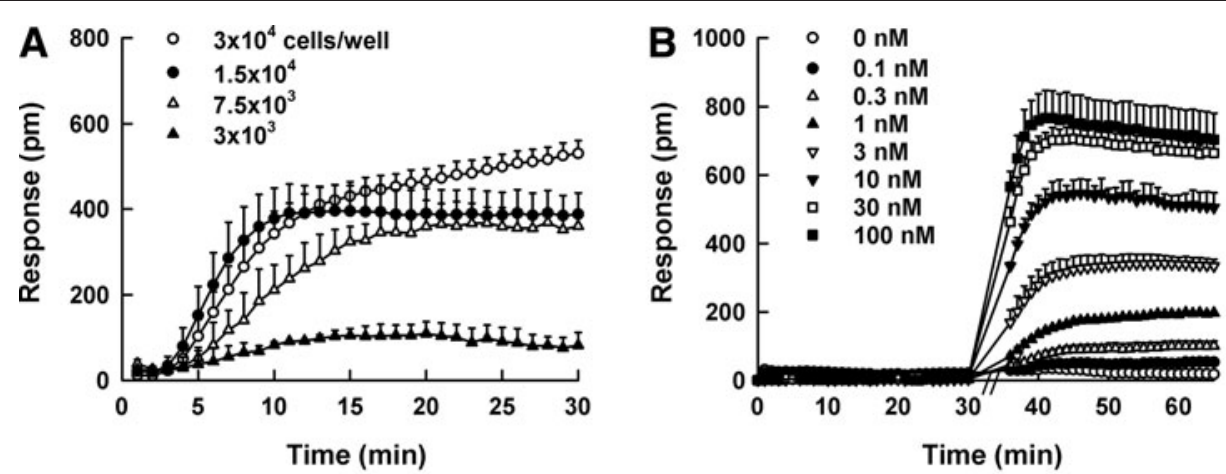

of $34.9 \pm 14.9 \mathrm{nM}$. In case of urantide, it behaved as a partial agonist resulting in positive efficacy in the DMR assay. As shown in Figure 5C, the treatment of urantide in UT receptor-expressing cells evoked concentration-dependent DMR increase with $\mathrm{EC}_{50}$ value of $9.6 \pm 3.3 \mathrm{nM}$. However, in the calcium mobilization assay, the agonist response by urantide was too low to determine the dose response (Fig. 6C).

In addition, as shown in Figure 7, the $\mathrm{IC}_{50}$ values for GSK1562590 (47.5 \pm 7.0 ,
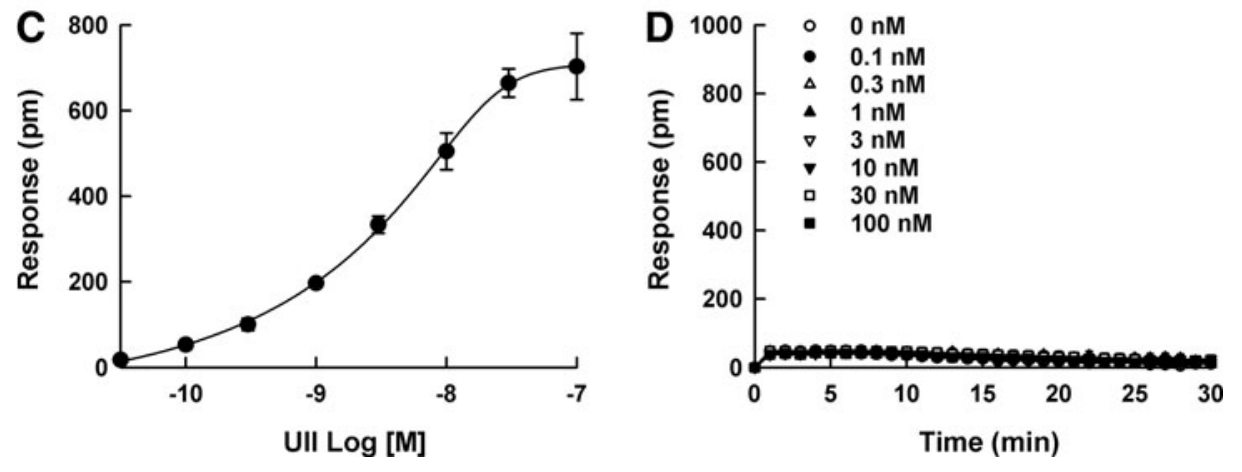

$50.2 \pm 11.2$, and $47.4 \pm 13.7 \mathrm{nM}$ at $0.3,3$, and $30 \mathrm{nM}$ of UII, respectively) in the DMR assay were almost same whether the challenge stimulus came from around $\mathrm{EC}_{20}$ to $\mathrm{EC}_{80}$ of UII $(0.3-30 \mathrm{nM})$. On the other hand, the antagonistic calcium response of GSK1562590 was measurable only at $30 \mathrm{nM}$ UII $(3.3 \pm 0.7 \mathrm{nM})$.

\section{DISCUSSION}

In the present study, we demon-

Fig. 1. Dynamic mass redistribution (DMR) responses of urotensin II (UII). (A) DMR response by $100 \mathrm{nM}$ UII at various HEK293ut cell densities in 384-well plates (3,000-30,000 cells/well). (B) Real-time kinetic responses of UII at various concentrations (o-100 nM) in HEK293ut cells. The final concentrations of Ull were indicated in the graph: $(\bigcirc)$ o $\mathrm{nM},(\bullet) 0.1 \mathrm{nM},(\triangle) 0.3 \mathrm{nM},(\Delta)$ $1 \mathrm{nM},(\nabla) 3 \mathrm{nM}(\boldsymbol{\nabla}) 10 \mathrm{nM},(\square) 30 \mathrm{nM}$, and ( $\square) 100 \mathrm{nM}$. (C) The DMR amplitudes of UII as a function of UII concentration. (D) No DMR response in parental HEK293 cells. All concentration responses represent the mean \pm SD of triplicate wells $(n=3)$.

strated the development and validation of the DMR assay and its application for the functional analysis of UT receptor antagonists. In addition, these experimental results from DMR technology were compared with the conventional calcium mobilization assay. Our work has been started by evaluating the op-

determination and the distribution of signal-to-background (S/B) data (Fig. 4). DMR signal from stimulation of UII (30 nM UII $=537 \pm$ 26, buffer control $=21 \pm 7$ P.M.) presented similar separation with calcium mobilization ( $30 \mathrm{nM}$ UII $=63709 \pm 4181$, buffer control $=2275 \pm 429 \mathrm{RFU})$. The calculated S/B ratios of the DMR and calcium mobilization assays were 25.6 and 28.0, respectively. The $Z^{\prime}$ factor for the DMR assay was calculated as 0.81 , representing similar signal stability of adding same UII concentration ( $30 \mathrm{nM})$ with the calcium mobilization assay (Z' factor: 0.77).

\section{DMR Responses Induced by Known UT Receptor \\ Antagonists}

SB657510 and GSK1562590, assumed to be antagonists, may behave as inverse agonists presenting negative efficacy in the DMR assay (Fig. 5A, B); however, these effects were not detected in the calcium mobilization assay (Fig. 6A, B). Although SB657510 exhibited negative efficacy in the DMR assay, the window was too shallow to quantitate the $\mathrm{EC}_{50}$ value of SB657510. GSK1562590 exerted stronger negative efficacy than $\mathrm{SB} 657510$ with $\mathrm{EC}_{50}$ value timum cell density for the DMR assay and calcium mobilization assay. The addition of $100 \mathrm{nM}$ UII elicited a positive DMR response, and the maximum DMR response was observed at a density of 30,000 cells/well of HEK293 $3_{\text {ut }}$ cells in 384-well plates. The maximum calcium signal was also observed at 100,000 cells/well in 96well plates. The optimum cell density was almost similar in both assays in terms of cell number versus working volume. In comparison of agonism performance between the DMR and calcium mobilization assays, the stimulation of UII at various concentrations (0-100 nM) to HEK293 ${ }_{\text {UT }}$ cells evoked positive responses in both the DMR and calcium assays in a concentration-dependent manner. The calculated $\mathrm{EC}_{50}$ value (4.58) for UII in the DMR assay was very similar with that in the calcium mobilization assay $(4.15 \mathrm{nM})$. Interestingly, the DMR and calcium responses were absent in parental HEK293 cells.

In antagonism study to validate the DMR and calcium mobilization assays with reference compounds, the known UT receptor antagonists, such as SB657510, GSK1562590, and urantide, presented a typical concentration-dependent antagonist response. The $\mathrm{IC}_{50}$ values of 

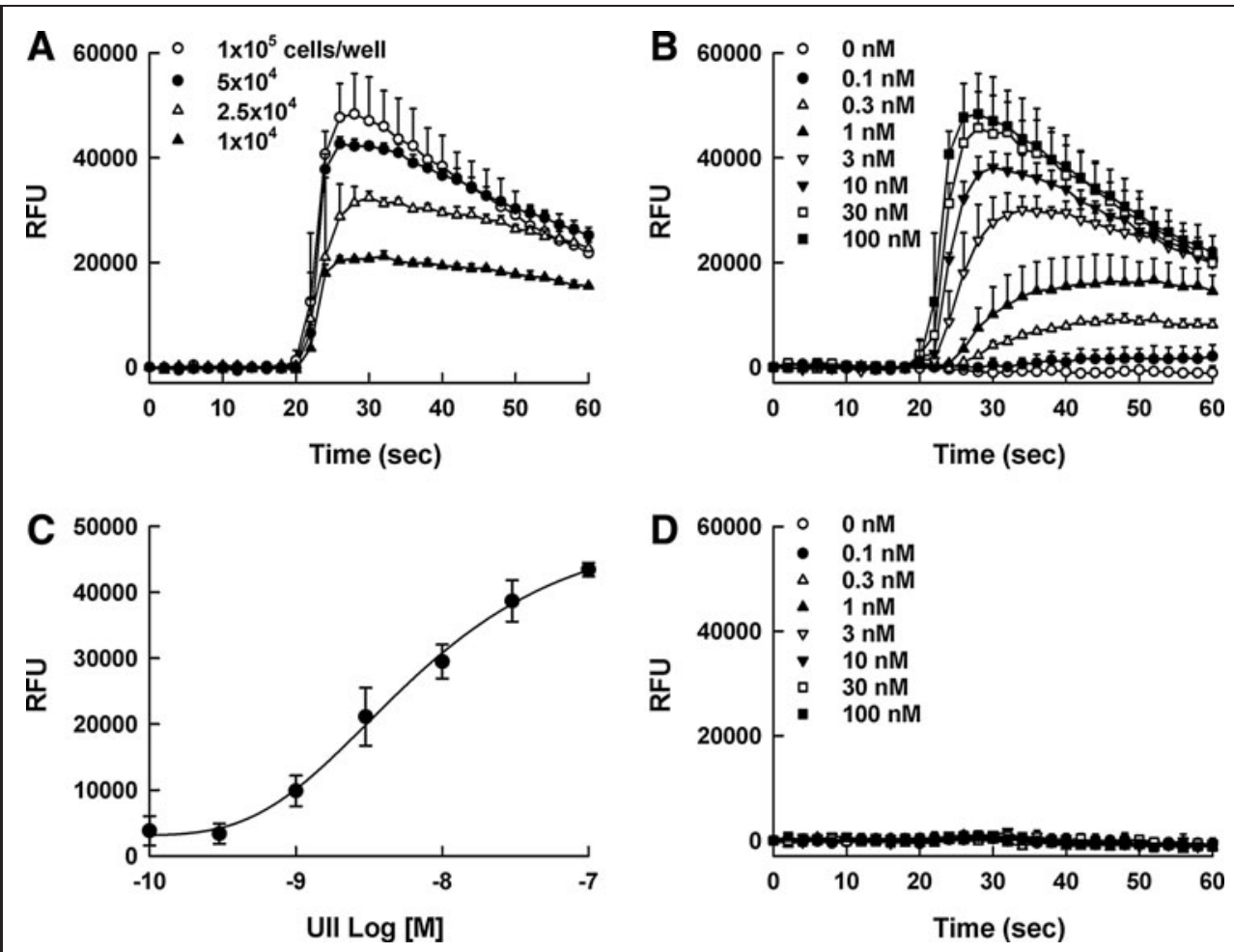

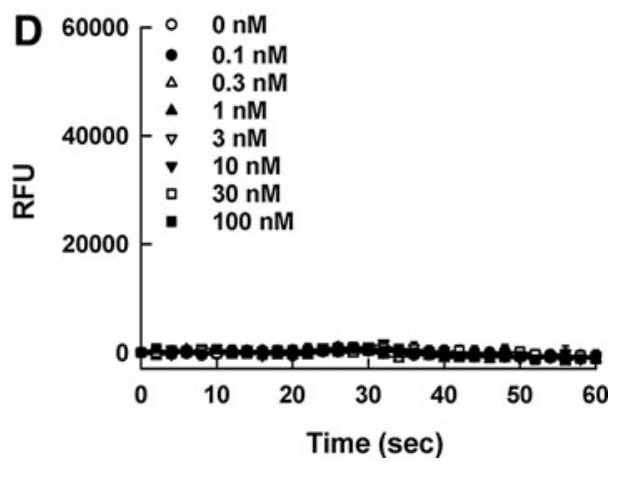

Fig. 2. Calcium signal responses of urotensin II (UII). (A) Calcium response by $100 \mathrm{nM}$ UII at various HEK293ut cell densities in 96-well plates (10,000-100,000 cells/well). (B) Real-time kinetic responses of UII at various concentrations (0-100 nM) in HEK293ut cells. The final concentrations of Ull were indicated in the graph: $(\bigcirc)$ o $n M,(\bullet) 0.1 \mathrm{nM},(\triangle) 0.3 \mathrm{nM},(\Delta) 1 \mathrm{nM},(\nabla) 3 \mathrm{nM}(\boldsymbol{\nabla}) 10 \mathrm{nM}$, ( $\square) 30 \mathrm{nM}$ and ( $\square$ ) $100 \mathrm{nM}$. (C) The calcium signal amplitudes of UII as a function of UII concentration. (D) No calcium response in parental HEK293 cells. All concentration responses represent the mean \pm SD of triplicate wells $(n=3)$.

SB657510, GSK1562590, and urantide in the DMR assay were 1,880, 47.4, and $10.7 \mathrm{nM}$, respectively, which were less potent than those in the calcium mobilization assay (528, 3.3 and $8.1 \mathrm{nM}$, respectively). The possible explanation of these differences may be in part due to selectivity of compounds as well as the measurements of an overall cellular response in the DMR assay rather than the target-mediated event along defined signaling pathway in the calcium mobilization assay. Indeed, some DMR studies has reported similar differences compared with other assays. ${ }^{19}$

The quality of DMR and calcium mobilization assays for UT receptor was evaluated by the $\mathrm{Z}^{\prime}$ factor determination and the distribution of signal-to-background (S/B) data. The S/B ratio provides an indication of separation of positive and negative control data that can be used to estimate the quality of an assay. The $\mathrm{Z}^{\prime}$ factor analysis is also a standard approach to evaluate the quality of assay for its potential use as a screening tool involving a large number of comparisons. ${ }^{20}$ Generally, the $Z^{\prime}$ factor greater than 0.5 was accepted as a qualified assay system for the HTS campaign. The DMR signal evoked by UII presented similar separation with calcium mobilization. The calculated S/B ratios of the
DMR and calcium mobilization assay were 25.6 and 28.0, respectively. The $\mathrm{Z}^{\prime}$ factor for the DMR assay was calculated as 0.81 , representing similar signal stability with the calcium mobilization assay ( $Z^{\prime}$ factor: 0.77). These results suggest that the DMR assay can achieve the desired sensitivity and reproducibility that can be adapted for cellbased functional assay. When comparing the two assays, DMR assay versus calcium mobilization assay, the DMR assay needs a significant cost for optical biosensor microplates, whereas the calcium mobilization assay needs various reagents, including fluorometric plates and the homogeneous calcium assay dye.

In inverse and partial agonism studies with reference compounds, SB657510 and GSK1562590 may behave as inverse agonists presenting negative efficacy in the DMR assay, whereas these negative effects were not detected in the calcium mobilization assay. In HEK293UT cells, treatment of SB657510 and GSK1562590 concentration dependently reduced the DMR response below the basal level. This result suggests that therapeutic actions of SB657510 and GSK1562590 may involve not only receptor blockade but also the decrease of spontaneous UT receptor population or activity. Recent study suggests that as many as $85 \%$ of tested antagonists behave as inverse agonist. ${ }^{21}$ The ability to differentiate the antagonist and/or inverse agonist properties is very important since this may help to guide a decision on the therapeutic administration. ${ }^{19}$ Although the possible physiological role of the inverse agonist is not evident in vivo, this type of new possibility has a significant meaning as there is pressing requests for the additional in vitro research tools to fill the gap between in vivo and in vitro.

Urantide, known as an antagonist, ${ }^{15}$ behaved as a partial agonist resulting in positive efficacy in the DMR assay. The treatment of urantide in UT receptor-expressing cells evoked concentrationdependent DMR increase with $\mathrm{EC}_{50}$ value of $9.6 \mathrm{nM}$. This result in the DMR assay suggests that therapeutic actions of urantide may involve not only receptor blockade against UII but also the partial increase of spontaneous UT receptor potential. However, in the calcium mobilization assay, the agonist response by urantide was too low to determine the agonist dose response. The normal S/B ratio for the UT 

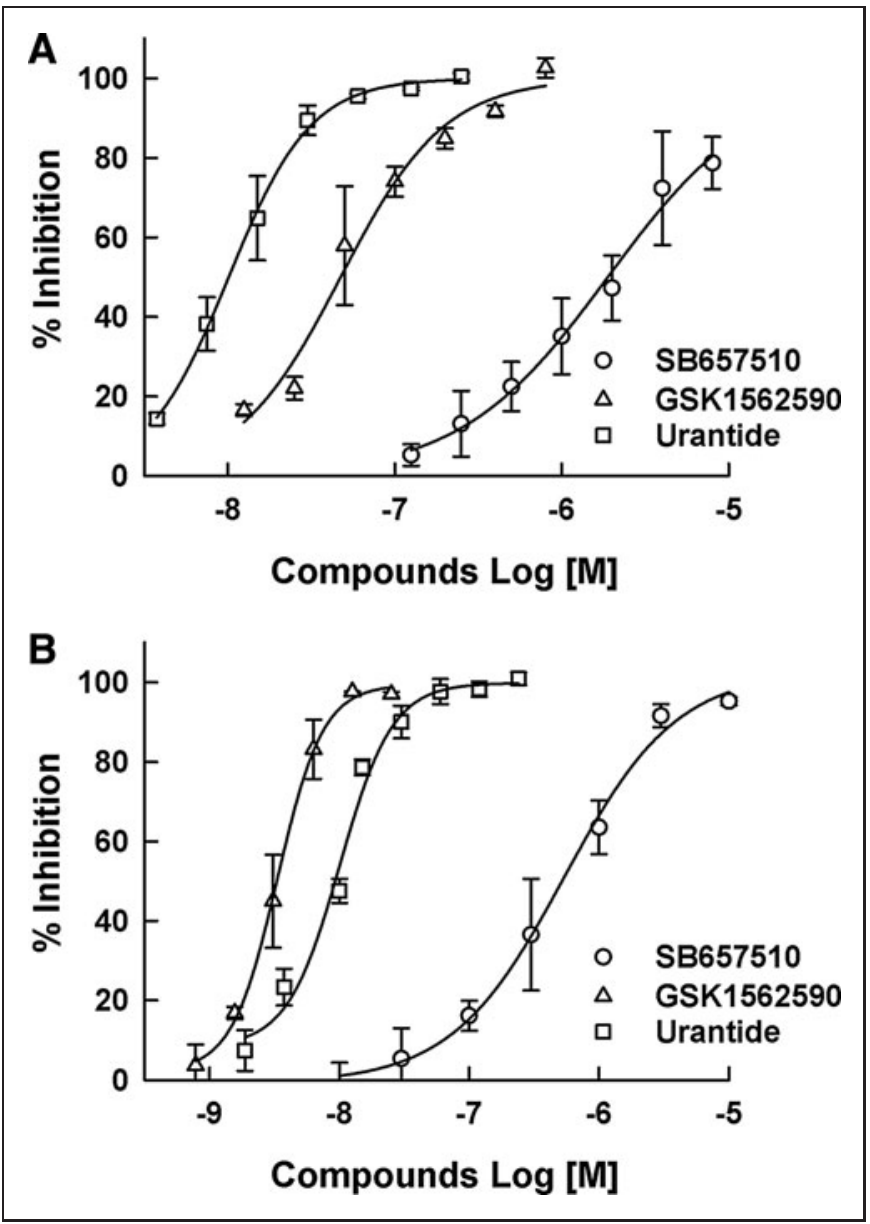

Fig. 3. The antagonist responses of $(O) \operatorname{SB657510,}(\triangle)$ GSK1562590, and ( $\square$ ) urantide as reference compounds. Doseresponse curves were generated in the $(A)$ dynamic mass redistribution assay and (B) calcium mobilization assay. Each assay was conducted as described in the Materials and Methods section. The percent inhibition was calculated as ([raw data of compoundMean $\left._{\mathrm{c}_{-}}\right] /\left[\right.$Mean $_{\mathrm{c}+}-$ Mean $\left.\left._{\mathrm{c}-}\right]\right) \times 100$. Data were expressed as the mean \pm SD of percent inhibition $(n=3)$.

receptor calcium assay was 28 , but the S/B ratio in agonist response by urantide was less than 2 .

In addition, an $\mathrm{EC}_{80}$ of agonist is typically used for antagonist screening in the calcium mobilization assay because it provides the necessary signal window for detecting inhibitory responses. ${ }^{22}$ However, as long as the signal window is robust, lower agonist treatment for the antagonist screening could be beneficial. In the DMR assay, the IC $_{50}$ values for GSK1562590 (47.5, 50.2, and $47.4 \mathrm{nM}$ at $0.3,3$, and $30 \mathrm{nM}$ of UII, respectively) were almost same whether the challenge stimulus came from various concentrations of UII. This concentration range $(0.3-30 \mathrm{nM})$ is around $\mathrm{EC}_{20}$ to $\mathrm{EC}_{80}$ of UII. These results suggest that the DMR assay could have a greater sensitivity over the calcium mobilization assay for detecting antagonists regardless of the degree of agonist stimulus.

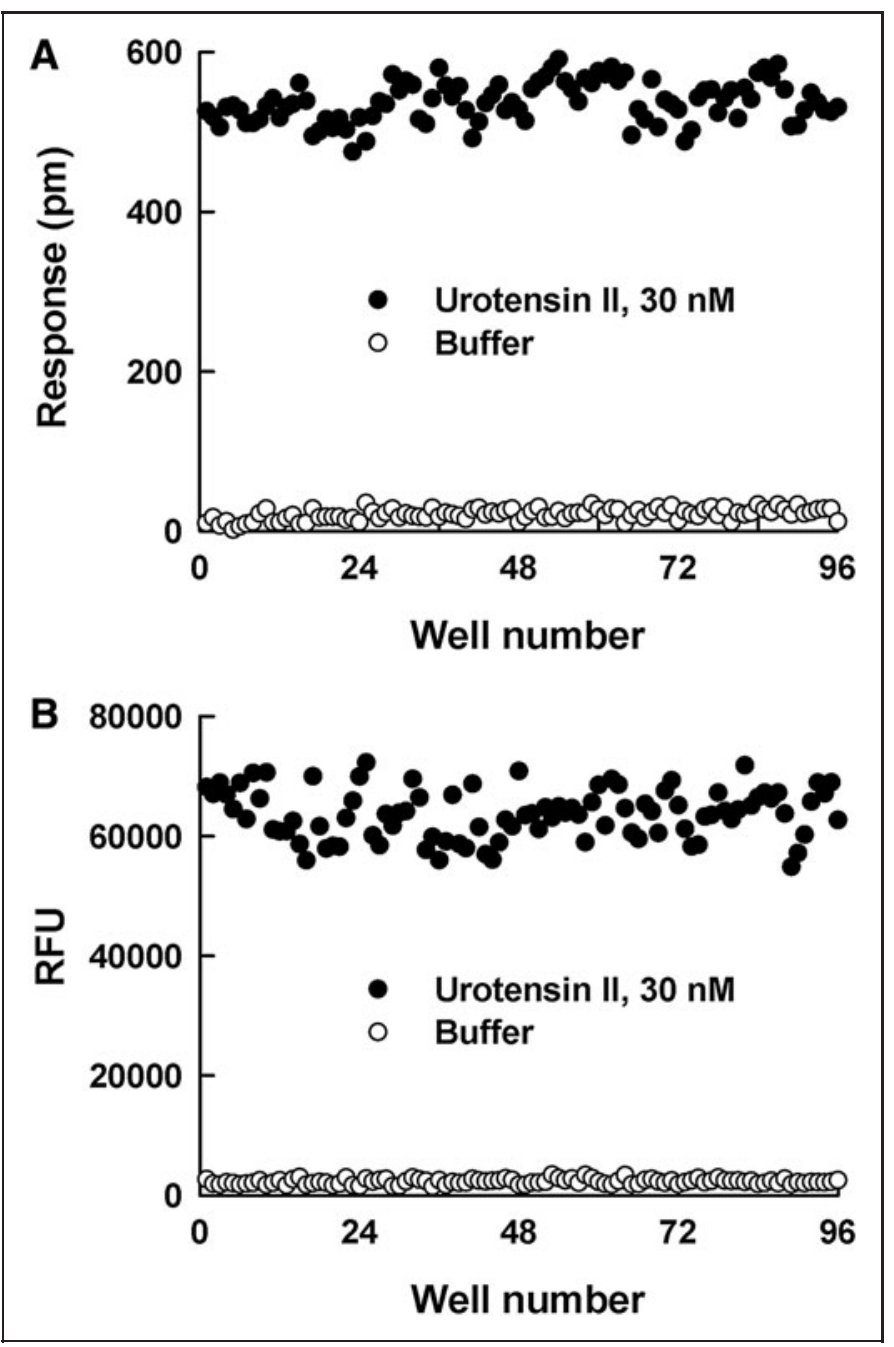

Fig. 4. Scatter plot of adding $(\bullet)$ 30 $\mathrm{nM}$ urotensin II and $(O)$ buffer control values from the (A) dynamic mass redistribution (DMR) assay and (B) calcium mobilization assay.

The DMR technology is an emerging tool in the research field of receptor biology as well as drug pharmacology. In this study, two different cell-based functional assays, such as DMR and calcium mobilization assay, were compared for performances to measure the functional activity of UT receptor antagonists. The DMR assay offers an integrated, quantitative, and dynamic representation of UT receptor activation. Moreover, this assay can allow us to characterize compound functions, such as agonist, antagonist, partial, and inverse agonists with its superior sensitivity. However, the calcium mobilization assay addressed classical agonist and antagonist functions in a cost-effective platform. Therefore, this DMR assay can be a strong addition for those conventional methods in the fields of receptor studies applicable to evaluate the functional activity of drug candidates for UT receptor. 


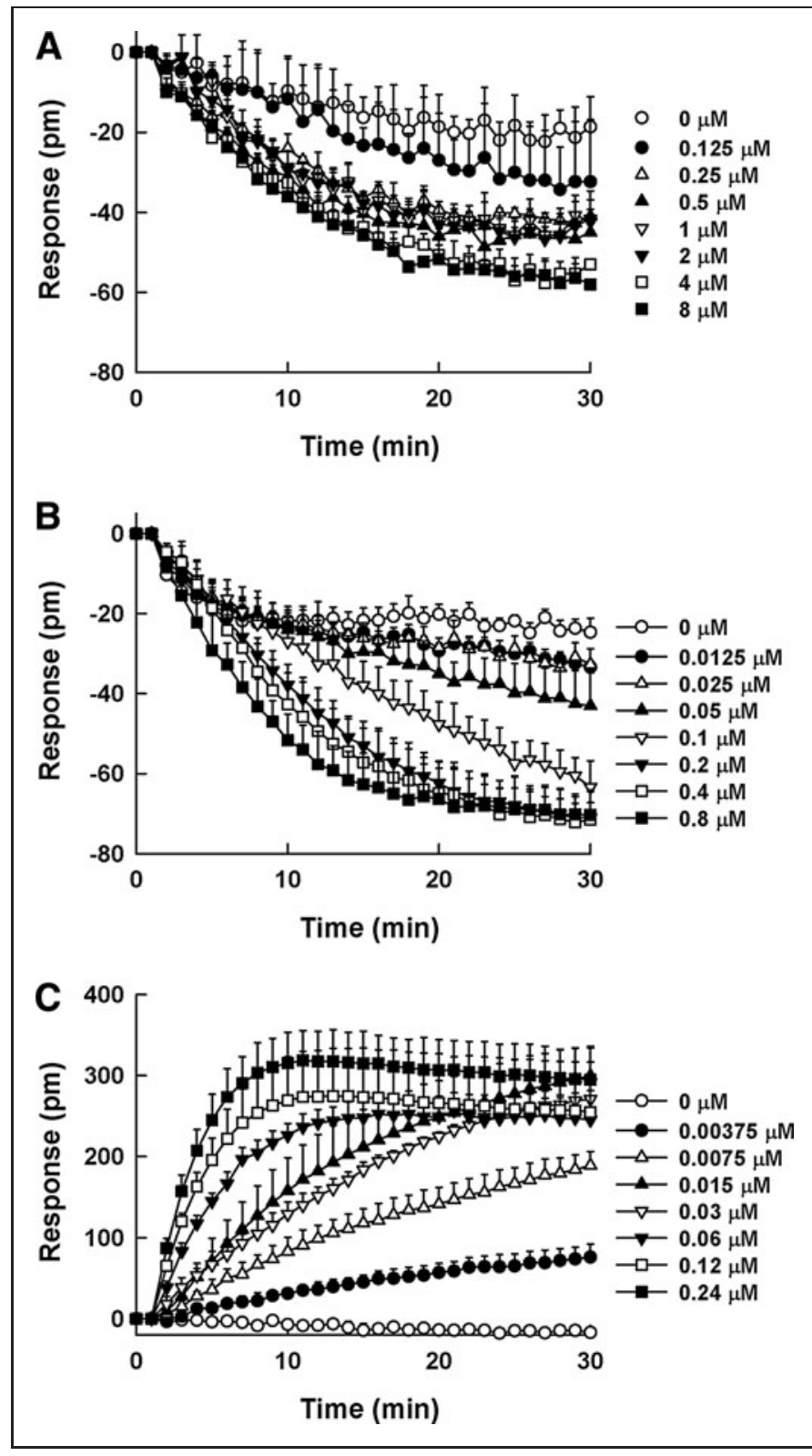

Fig. 5. Dynamic mass redistribution (DMR) profiles of SB657510 (A), GSK1562590 (B), and urantide (C) as reference compounds in HEK293ut cells. The cells in individual wells were incubated with the reference compounds at various concentrations for $30 \mathrm{~min}$ after taking a 5 min DMR baseline measurement [SB657510: $(O) \circ \mu \mathrm{M}$, (•) $0.125 \mu \mathrm{M},(\triangle) 0.25 \mu \mathrm{M},(\Delta) 0.5 \mu \mathrm{M},(\nabla) 1 \mu \mathrm{M},(\boldsymbol{\nabla}) 2 \mu \mathrm{M},(\square)$ $4 \mu \mathrm{M}$, and (ם) $8 \mu \mathrm{M}$; GSK1562590: $(\bigcirc) 0 \mu \mathrm{M},(\bullet) 0.0125 \mu \mathrm{M},(\triangle)$ $0.025 \mu \mathrm{M},(\Delta) 0.05 \mu \mathrm{M},(\nabla) 0.1 \mu \mathrm{M},(\boldsymbol{\nabla}) 0.2 \mu \mathrm{M},(\square) 0.4 \mu \mathrm{M}$, and

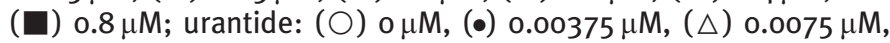

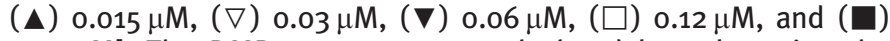
$0.24 \mu \mathrm{M}$ ]. The DMR response was calculated by subtracting the baseline measurement from the peak response intensity for each compound concentration. All concentration responses represent the mean \pm SD of triplicate wells $(n=3)$.

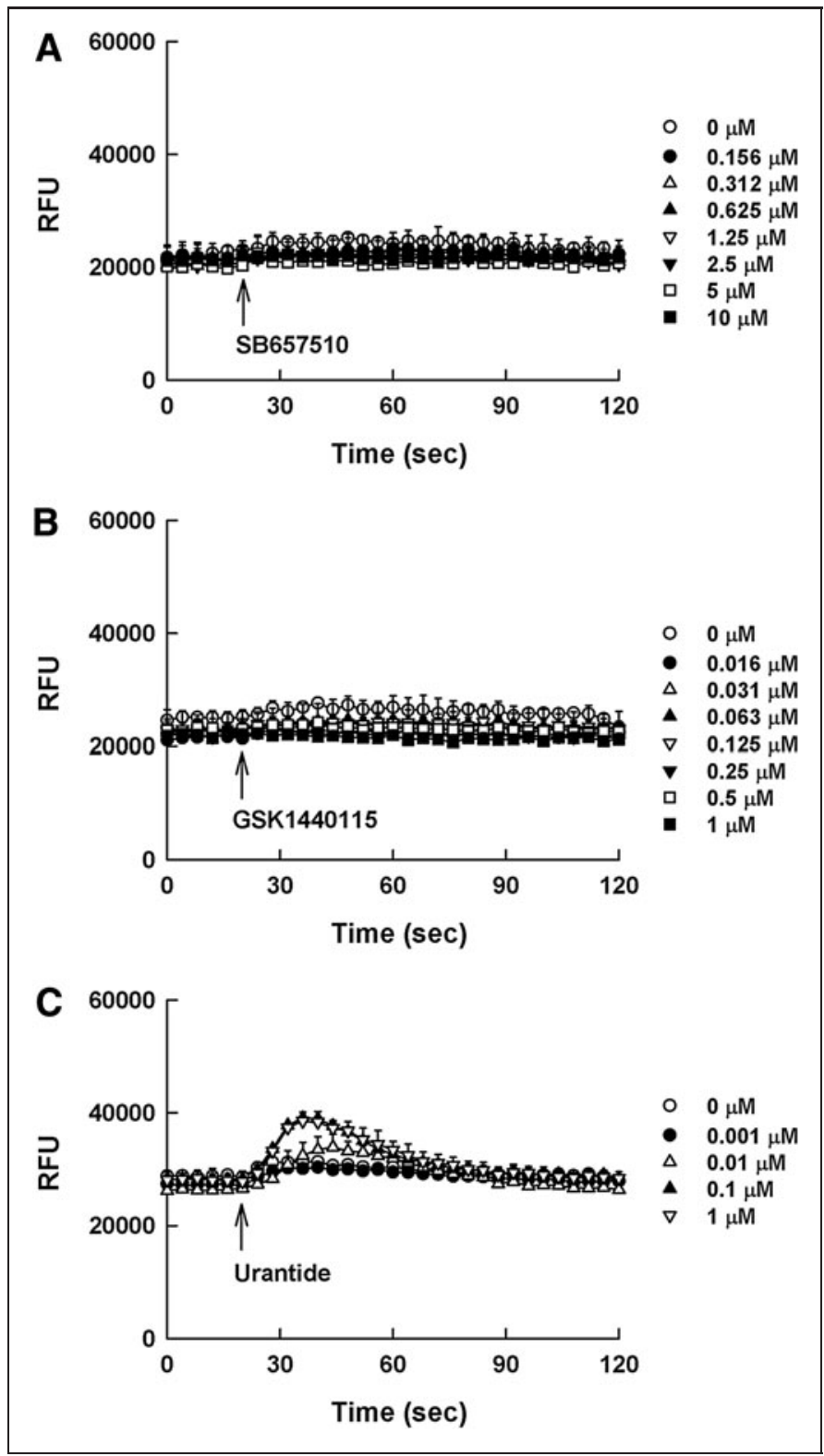

Fig. 6. Calcium profiles of SB657510 (A), GSK1562590 (B), and urantide (C) as reference compounds in HEK293ut cells. The cells in individual wells were incubated with the reference compounds at various concentrations for $120 \mathrm{~S}$ after taking a $20 \mathrm{~S}$ DMR baseline measurement [SB657510: $(\bigcirc)$ o $\mu \mathrm{M},(\bullet) 0.156 \mu \mathrm{M},(\triangle) 0.312 \mu \mathrm{M},(\boldsymbol{\Delta})$ $0.625 \mu \mathrm{M},(\nabla) 1.25 \mu \mathrm{M}$, ( $\boldsymbol{\nabla}) 2.5 \mu \mathrm{M},(\square) 5 \mu \mathrm{M}$, and ( $\square) 10 \mu \mathrm{M}$; GSK1562590: $(\bigcirc)$ o $\mu \mathrm{M},(\bullet) 0.016 \mu \mathrm{M},(\triangle) 0.031 \mu \mathrm{M},(\Delta) 0.063 \mu \mathrm{M}$, $(\nabla) 0.125 \mu \mathrm{M},(\nabla) 0.25 \mu \mathrm{M},(\square) 0.5 \mu \mathrm{M}$, and $(\square) 1 \mu \mathrm{M}$; urantide: $(\bigcirc)$ $0 \mu \mathrm{M},(\bullet) 0.001 \mu \mathrm{M},(\triangle) 0.01 \mu \mathrm{M},(\Delta) 0.1 \mu \mathrm{M},(\nabla) 1 \mu \mathrm{M}$. All concentration responses represent the mean \pm SD of triplicate wells $(n=3)$.

\section{ACKNOWLEDGMENTS}

This study was supported by a grant of the Technology Innovation Program (10038744) of Korea Evaluation Institute of Industrial Technology (KEIT) funded by MOTIE and by a grant of the Korea Healthcare Technology R\&D Project (A100096), MOHW, Republic of Korea. 


\section{LEE ET AL.}

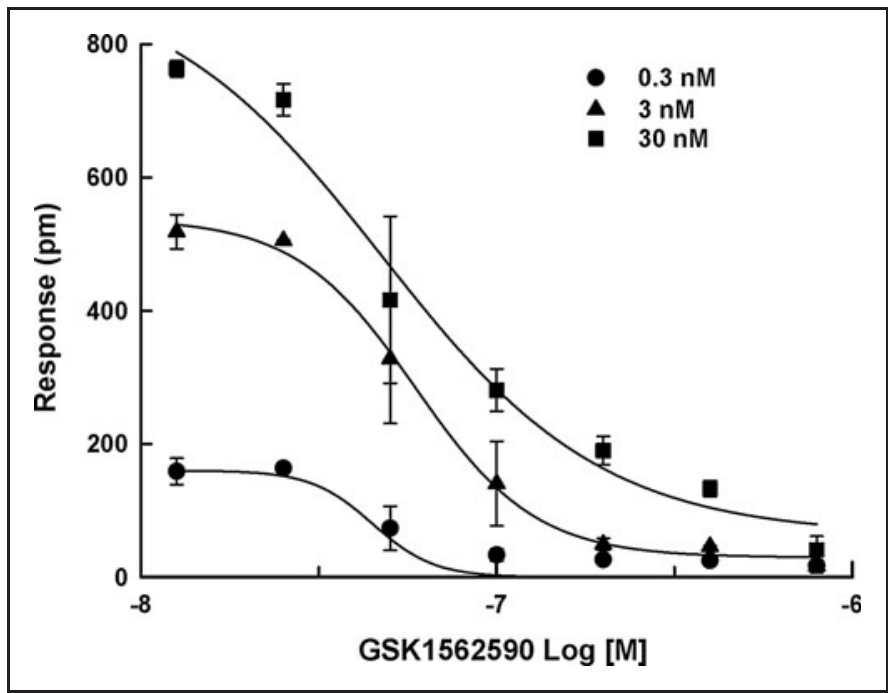

Fig. 7. The antagonistic response of GSK1562590 at (•) $0.3,(\boldsymbol{\Delta}) 3$, and ( $\square) 30 \mathrm{nM}$ of UII. The concentration range $(0.3-30 \mathrm{nM})$ is around $\mathrm{EC}_{20}$ to $\mathrm{EC}_{80}$ of UII. Data were expressed as the mean $\pm \mathrm{SD}$ of triplicate wells $(n=3)$.

\section{DISCLOSURE STATEMENT}

No competing financial interests exist.

\section{REFERENCES}

1. Ames RS, Sarau HM, Chambers JK, Willette RN, Aiyar NV, Romanic AM, et al.: Human urotensin-II is a potent vasoconstrictor and agonist for the orphan receptor GPR14. Nature 1999;401:282-286.

2. Bousette N, Giaid A: Urotensin-II and cardiovascular diseases. Curr Hypertens Rep 2006;8:479-483.

3. Nakayama $T$, Hirose $T$, Totsune $K$, Mori N, Maruyama $Y$, Maejima $T$, et al.: Increased gene expression of urotensin II-related peptide in the hearts of rats with congestive heart failure. Peptides 2008;29:801-808.

4. Marshall WS, Bern HA: Teleostean urophysis: urotensin II and ion transport across the isolated skin of a marine teleost. Science 1979;204:519-521.

5. Coulouarn $Y$, Lihrmann I, Jegou S, Anouar $Y$, Tostivint $H$, Beauvillain JC, et al.: Cloning of the cDNA encoding the urotensin II precursor in frog and human reveals intense expression of the urotensin II gene in motoneurons of the spinal cord. Proc Natl Acad Sci USA 1998;95:15803-15808.

6. Marshall IC, Owen DE, McNulty $\mathrm{S}$ : Measuring $\mathrm{Ca}^{2}+$ changes in multiwell format using the Fluorometric Imaging Plate Reader. Methods Mol Biol 2005;312:125-131.

7. Camarda V, Guerrini R, Kostenis E, Rizzi A, Calò G, Hattenberger A, et al.: A new ligand for the urotensin II receptor. Br J Pharmacol 2002;137:311-314.

8. Thomsen W, Frazer J, Unett D: Functional assays for screening GPCR targets. Curr Opin Biotechnol 2005;16:655-665.

9. Peters MF, Vaillancourt F, Heroux M, Valiquette M, Scott CW: Comparing labelfree biosensors for pharmacological screening with cell-based functional assays. Assay Drug Dev Technol 2010;8:219-227.

10. Schröder R, Janssen N, Schmidt J, Kebig A, Merten N, Hennen $S_{\text {, et al: }}$ Deconvolution of complex $\mathrm{G}$ protein-coupled receptor signaling in live cells using dynamic mass redistribution measurements. Nat Biotechnol 2010;28:943-949.

11. Schröder R, Schmidt J, Blättermann S, Peters L, Janssen N, Grundmann M, et al.: Applying label-free dynamic mass redistribution technology to frame signaling of $\mathrm{G}$ protein-coupled receptors noninvasively in living cells. Nat Protoc 2011;6: $1748-1760$
12. Fang Y, Ferrie AM, Fontaine NH, Yuen PK: Characteristics of dynamic mass redistribution of epidermal growth factor receptor signaling in living cells measured with label-free optical biosensors. Anal Chem 2005;77:5720-5725.

13. Fang $Y, L i G$, Ferrie AM: Non-invasive optical biosensor for assaying endogenous G protein-coupled receptors in adherent cells. J Pharmacol Toxicol Methods 2007;55:314-322.

14. Behm DJ, McAtee JJ, Dodson JW, Neeb MJ, Fries HE, Evans CA, et al.: Palosuran inhibits binding to primate UT receptors in cell membranes but demonstrates differential activity in intact cells and vascular tissues. Br J Pharmacol 2008; 155:374-386

15. Patacchini $R$, Santicioli $P$, Giuliani $S$, Grieco $P$, Novellino $E$, Rovero $P$, et al.: Urantide: an ultrapotent urotensin II antagonist peptide in the rat aorta. $\mathrm{Br} J$ Pharmacol 2003;140:1155-1158.

16. Behm DJ, Aiyar NV, Olzinski AR, McAtee JJ, Hilfiker MA, Dodson JW, et al:: GSK1562590, a slowly dissociating urotensin-II receptor antagonist, exhibits prolonged pharmacodynamic activity ex vivo. Br J Pharmacol 2010;161:207-228.

17. Lehner U, Velić A, Schroter R, Schlatter E, Sindić A: Identification of urotensin II as the endogenous ligand for the orphan G-protein-coupled receptor GPR14. Cell Physiol Biochem 2007;20:181-192.

18. Kassack MU, Höfgen B, Lehmann J, Eckstein N, Quillan JM, Sadée W: Functional screening of $G$ protein-coupled receptors by measuring intracellular calcium with a fluorescence microplate reader. J Biomo/ Screen 2002;7:233-246.

19. Lee PH, Gao A, van Staden C, Ly J, Salon J, Xu A, et al.: Evaluation of dynamic mass redistribution technology for pharmacological studies of recombinant and endogenously expressed g protein-coupled receptors. Assay Drug Dev Technol 2008;6:83-94

20. Zhang $J H$, Chung TD, Oldenburg KR: A simple statistical parameter for use in evaluation and validation of high throughput screening assays. J Biomol Screen 1999:4:67-73.

21. Kenakin T: Efficacy as a vector: the relative prevalence and paucity of inverse agonism. Mol Pharmacol 2004;65:2-11.

22. Noblin DJ, Bertekap Jr., RL, Burford NT, Hendricson A, Zhang L, Knox R, et al.: Development of a high-throughput calcium flux assay for identification of all ligand types including positive, negative, and silent allosteric modulators for $\mathrm{G}$ protein-coupled receptors. Assay Drug Dev Technol 2012;10:457-467.

Address correspondence to: Kwang-Seok Oh, PhD Research Center for Drug Discovery Technology Korea Research Institute of Chemical Technology

141 Gajeong-ro, Yuseong

Daejeon 305-343

Republic of Korea

E-mail:ksoh@krict.re.kr

Abbreviations Used

$\mathrm{DMR}=$ dynamic mass redistribution

DMSO $=$ dimethyl sulfoxide

$\mathrm{EC}_{50}=50 \%$ effective concentration

GSK1562590 = 4' - [(1R)-1-[[(6,7-Dichloro-3-oxo-2,3-dihydro-4H-1,4-benzoxazin4-yl)acetyl](methyl)amino]-2-(pyrrolidin-1-yl)ethyl]biphenyl-3carboxamide

$\mathrm{IC}_{50}=50 \%$ inhibitory concentration

SB657510 $=$ [2-bromo-N-[4-chloro-3-((R)-1-methyl-pyrrolidin-3-yloxy)phenyl]-4,5-dimethoxybenzenesulfonamide $\mathrm{HCl}$

$\mathrm{UII}=$ Urotensin $\|$

Urantide $=\mathrm{L}$-Aspartyl-L-penicillaminyl-L-phenylalanyl-D-tryptophyl-Lornithyl-L-tyrosyl-L-cysteinyl-L-valine cyclic disulfide

UT receptor $=$ Urotensin receptor 